\begin{tabular}{|c|c|}
\hline$\prod_{\text {People }} \prod_{\substack{\text { Profit } \\
\text { CSRᄃ }}}$ & $\begin{array}{c}\text { Volume and Issues Obtainable at Center for Sustainability Research and } \\
\text { Consultancywww.globalcsrc.org } \\
\text { Journal of Business and Social Review in Emerging Economies } \\
\text { ISSN: 2519-089X; (Online) 2519-0326 } \\
\text { Volume 2: Issue 2December } 2016\end{array}$ \\
\hline
\end{tabular}

\title{
Re-examining Family Communication Pattern: The Confirmatory Factor Analysis
}

\author{
${ }^{1}$ Aziyah Abu Bakar, ${ }^{2}$ ZarihanSamsudin, ${ }^{3}$ AsyrafAfthanorhan \\ ${ }^{1,2}$ Senior Lecturer, School of Humanities and Social Sciences, Kolej University Poly-Tech Mara \\ Malaysiaaziyah@kuptm.edu.my \\ ${ }^{3}$ Faculty of Economics and Management Sciences, University Sultan Zainal Abidin Malaysia \\ ash_18raft@yahoo.com
}

\begin{tabular}{l}
\hline ARTICLEDETAILS \\
History \\
Revised format: Nov 2016 \\
AvailableOnline: Dec 2016 \\
\\
\hline Keywords \\
Family Communication \\
Pattern, Confirmatory Factor \\
Analysis, \\
Fitness Index, \\
Reliability test \\
\hline
\end{tabular}

JEL Classification:

$J 13, D 57, D 59$

\begin{abstract}
Objective: The purpose of this paper is to determine whether the model for Revised Family Communication Pattern (RFCP) can be used to measure the communication patterns within a family.

Methodology: A survey questionnaire was administered to 500 respondents but only 380 of them were deemed useable. Prior to this, a pilot study was undertaken in which an internal alpha procedure was conducted to determine the reliability of the variables for this study. Similarly, the Confirmatory Factor Analysis (CFA) was also performed to confirm the factor structure so that variables with low factor loading could be excluded. On the other hand, the variable with highest factor loading was identified and then rigorously explained in regard to this model.

Results: More than 50\% of the respondents had agreed with the item B9 of the conversation orientation and B17 of the conformity orientation thus, indicating that the model is useful in measuring the communication patterns within a family after omitting several effect indicators that had severe negative impact on estimation.

Implications: When the value of factor loading of a variable is low, fitting the variable in the model will result in the model becoming a misfit that ends with a discussion about the underlying factor structure that is fruitless. This study is particularly useful for practitioners who need to identify variables that are suitable for research on family communication. Besides that, this paper also provides valuable reference for researchers to consider the adoption of RFCP based on conversation and conformity orientations in Malaysia.
\end{abstract}

(C) 2016 The authors, under a Creative Commons AttributionNonCommercial 4.0

\section{Introduction}

A person's happiness when he is with his family depends on a number of internal and external factors. *Corresponding author's email address: aziyah@kuptm.edu.my

Recommended citation: Bakar, A.A., Shamsudin, Z., Afthanorhan, A. (2016). Re-examining Family Communication Pattern: The Confirmatory Factor Analysis. Journal of Business and Social Review in Emerging Economies,2(2) 101-108. DOI: https://doi.org/10.26710/jbsee.v2i2.26 
An internal factor such ascommunication for example can cause a family to functionwell or badly(Caro, 2011). This is because good communicationbetweenfamily memberscancreate afamily-friendly atmosphere(Simpkins et al., 2006; Park, 2008). Such atmosphere in turn promotes healthy relationship between parents and children. In such families, children usually consulttheir parents when they are confronted with any kinds ofproblems. This indicates the importance of communication in ensuring happiness among family members. This isconsistent with thestatement madebyKoerner and Fitzpatrick(2004) who point outthatcommunicationwithin a familyis indeed a"tool" to measurehappinessin the family. More essentially, family communicationpatternsare the factors that shape thepersonalityof the children in the family because these children can be influenced to become responsible, obedientandrespectful person to others through them. Similarly,Fosco and Grych(2008) seem to think that childrenwill in turn pass on thecommunicationpatterns they practice with their parentstotheir children. In view of this, studiesrelated tofamilycommunicationis not only vital but necessary.

Manystudies on family communication have adopted themeasurement of RevisedFamilyCommunicationPatterns(RFCP) proposed by byRitchieandFitzpatrick(1990) in measuring thecommunication patternswithin a family (Laursen\& Collins, 2004). In so far, twodimensional patternsof family communication have been introduced, namelyconversationorientationandconformityorientation. Conversation orientation is a two-way form of communication.Families who adopt this orientation are families with parents who are more open and those who usually help or together with their children to express their views and opinion about something. These parentsalsooftensupport and cooperate with their children by engaging inactivities thatare accompaniedby their children. In other words, parentswhoare conversation oriented are parents who welcome the presence and existence of their children. On the other hand, conformity orientation isaform ofone-way communication. Parents of familieswhoadoptconformityorientationaremoreassertive, unfriendlyandaloof toward their children. Childrenof these families are often asked tocomplywiththe instructions andregulationsprovided by theirparents. In other words, parentswhoadoptconformityorientation areparentswho pay great attention on self-discipline onchildren(Koerner\&Fitzpatrick, 2004).

Based onprevious studies, manystudies onfamilycommunicationare associatedwithother variablessuch asyoung people's behaviors, familyconflicts, socialmedia, media technology,andothers (Hicks, 2000; Chan \& McNeal, 2003; Nuredayu, et al., 2004).In measuringthe impact ofa certain phenomenonandthe like, the measurementof familycommunication patterns can be appliedin the collection of data. By obtainingCronbach's alpha, it is found that the value of negligencefor eachitem exceeds 0.7. This means that Revised FamilyCommunicationPatterns (RFCP) have indicated validityas well as reliability. The consistency shown acrossseveralprevious studieshasestablished themeasurement of RFCP and hence, itsmany adoptions(Chan \& McNeal, 2003; Braithwaite et al., 2003; Koerner \& Fitzpatrick, 2004). In view of this, this study seeks toanalyzethemeasurementRFCP by using Confirmatory Factor Analysis (CFA) to see the differences in results. As this is a rarestudy and undertaken specificallyonitemscontainedin the measurement offamilycommunication patterns, it is the objectiveof this study to look at the numberof itemsandthose itemswhichareselectedafter the analysis of theCFAprocess.

\section{Literature review}

\subsection{Family Communication Pattern}

In family communication, communication patterns strongly influence the life of a family.Familycommunication patterns usually create communication environmentthatis either positive 
or negative depending onhowa familymanagescommunication patternsin their families (Koerner\&Fitzpatrick, 2004; Bakar \&Afthanorhan, 2016). Each family normally establishes its own communication patterns (Braithwaite, McBride \& Schrodt, 2003).A patternof communication favored by familyA might not be able to bepracticedby familyB.Perhaps, the family communication environment of family $\mathrm{A}$ is harmonious while that offamilyBisnoisyanddisturbing. Therefore, it is vital to know the patterns of family communication and their influence.

A communicationpatterninfluences every family's tendency to form its daily communication. It is formed during the process ofcreating and sharing of interactions among its members. Communication patterns that are practiced and exhibited by parents strongly influence their children's lives because these patterns shape these children's behavioral pattern (Galvin, Braithwaite, \& Bylund, 2015). According to McLeod et al. (1972), a family communication pattern can either be concept oriented and socio oriented. However, Ritchie andFitzpatrick(1990) change the name concept oriented family communication to conversationoriented and that of the socio oriented to conformityoriented. AccordingKoerner\& Fitzpatrick(2004), family communication pattern which is conversation oriented emphasizes on discussion, opinions and ideas among family memberswhereasconformity oriented one stresses onconsistency inbehavior, values and beliefsamong family members.

\subsection{MeasurementRevisedFamilyCommunicationPatterns}

The measurement offamilycommunication patternshad been developedbyMcLeodandChaffeein 1972. They categorized the patterns of family communication into dimension, namely conceptorientationandsocio orientation. There are 14 items in the measurement of family communication patterns for which 7 itemsbelong toconceptorientation and another 7 items tosocioorientation. A Likert Scale is usually used to measure thecommunication patternswithin the family.

At the beginning of 1990s, RitchieandFitzpatrickmodifiedthe earlier mentioned measurement and renamed it as RevisedFamilyCommunicationPattern. A total of 26 itemswere next included into the new measurement. Out of the 26 items, 15 made up to conversation orientation while the remainder 11 items consisted of conformity orientation(Ritchie andFitzpatrick, 1990). These itemsare listed below.

Table 1: CronbachAlpha( $\alpha$ ) of eachitemaccording to Revised ofFamilyCommunication Patterns(RFCP)

\begin{tabular}{|l|l|c|}
\hline No & Conversation orientation & $\begin{array}{c}\text { Cronbach } \\
\text { Alpha (a) }\end{array}$ \\
\hline 1 & $\begin{array}{l}\text { In our family we often talk about topics like politics and religion where } \\
\text { some people disagree with others }\end{array}$ & 0.80 \\
\hline 2 & $\begin{array}{l}\text { My parents often say something like, "Every member of the family should } \\
\text { have some say in family decision." }\end{array}$ & 0.78 \\
\hline 3 & $\begin{array}{l}\text { My parents often ask my opinion when the family is talking about } \\
\text { something. }\end{array}$ & 0.78 \\
\hline 4 & My parents encourage me to challenge their ideas and beliefs. & 0.78 \\
\hline 5 & $\begin{array}{l}\text { My parents often say things like "You should always look at both sides of } \\
\text { an issue." }\end{array}$ & 0.80 \\
\hline 6 & I usually tell my parents the things I am thinking about. & 0.80 \\
\hline 7 & I can tell my parents about almost anything. & 0.78 \\
\hline 8 & My family members often talk about our feelings and emotions. & 0.77 \\
\hline
\end{tabular}




\begin{tabular}{|c|c|c|}
\hline 9 & $\begin{array}{l}\text { My parents and I often have long, relaxed conversations about nothing in } \\
\text { particular. }\end{array}$ & 0.78 \\
\hline 10 & $\begin{array}{l}\text { I really enjoy talking with my parents, even when we disagree about } \\
\text { something. }\end{array}$ & 0.77 \\
\hline 11 & My parents encourage me to express my feelings. & 0.77 \\
\hline 12 & My parents are very open about their emotions. & 0.78 \\
\hline 13 & We often talk as a family about things we have done during the day. & 0.77 \\
\hline 14 & My family members often talk about our plans and hopes for the future. & 0.78 \\
\hline \multirow[t]{2}{*}{15} & $\begin{array}{l}\text { My parents like to hear my childish opinion, even when I don't agree with } \\
\text { them. }\end{array}$ & 0.77 \\
\hline & Conformity orientation & \\
\hline 16 & $\begin{array}{l}\text { When it involves anything important, my parents expect me to obey without } \\
\text { question. }\end{array}$ & 0.78 \\
\hline 17 & In our home, my parents usually have the last word. & 0.77 \\
\hline 18 & My parents feel that it is important to be the boss. & 0.77 \\
\hline 19 & $\begin{array}{l}\text { My parents sometimes become irritated with my views especially when } \\
\text { mine are different from theirs. }\end{array}$ & 0.76 \\
\hline 20 & If my parents don't approve of anything, they don't want to know about it. & 0.77 \\
\hline 21 & When I am at home, I am expected to obey my parents' rules. & 0.77 \\
\hline 22 & My parents often say things like "You'll know better when you grow up" & 0.80 \\
\hline 23 & $\begin{array}{l}\text { My parents often say things like "My ideas are right and you should not } \\
\text { question them". }\end{array}$ & 076 \\
\hline 24 & My parents often say things like "A child should not argue with adults." & 0.80 \\
\hline 25 & $\begin{array}{l}\text { My parents often say things like "There are some things that just shouldn't } \\
\text { be talked about." }\end{array}$ & 0.77 \\
\hline 26 & $\begin{array}{l}\text { My parents often say things like "You should give in on arguments rather } \\
\text { than risk making people mad." }\end{array}$ & 0.79 \\
\hline
\end{tabular}

Based on Table 1, the items in this measurement have Cronbach alpha values that are above 0.70.Severalprevious studieshad shownsimilar results. For example, a study conducted byChan and McNeal (2003) showedCronbachalphavalues which were alsoabove0.70. Based on the findingsobtainedfromthe analysis ofthe results ofSPSS, the present studydecided to placeall the itemsunderCFAanalysis so as to come up with a new perspective on measuring Revised Family Communication Patterns.

\section{Methodology}

This study was a cross-sectional one and therefore, required instruments like questionnaire to collect its data. It was one which utilized a 10-point Likert scale whose rating ranged from (1) strongly disagree to (10) strongly agree. This scale was deemed suitable because like other studies of this kind, this study had employed a parametric technique whose minimum requirement scale was in the form of interval scale (Awang, Afthanorhan, \&Mamat, 2016). This scale had enabled the respondents of the study to rate their perceptions or opinions based on the questions presented. Nonetheless, the requirement that allowed the researchers of this study to use a parametric technique was not limited only to the measurement scale but also the use of probability sampling. In this case of this study, the data had been collected via cluster random sampling that involved samples from the east-coast towns in Malaysia such 
as Kota Bharu (Kelantan), Kuantan (Pahang), and Kuala Terengganu (Terengganu). The target population for this study consisted of Form 4 students from national schools. Five hundred sets of questionnaire had been distributed but only 380 were deemed useable while the rest were not because either they were not returned or not sufficiently and appropriately completed.

The analysis using Statistical Package for Social Science (SPSS) and that of the Moment of Structure (AMOS) were undertaken to assess the Family Communication Patterns and then to determine which of the items had made high contributions to the findings of the study. Using SPSS, the Cronbach Alpha procedure was utilized to determine the reliability of each item involved in the study. Once the items had been tested for reliability, the Family Communication Patterns was next constructed and validated using the Confirmatory Factor Analysis (CFA). As for the application of AMOS, the structural equation model has been used. The adoption of structural equation modeling, however, entails two sub-models that are measurement model and structural model. Apart from that, this present paper also assesses the quality of constructs in the form of measurement model.

\section{Results}

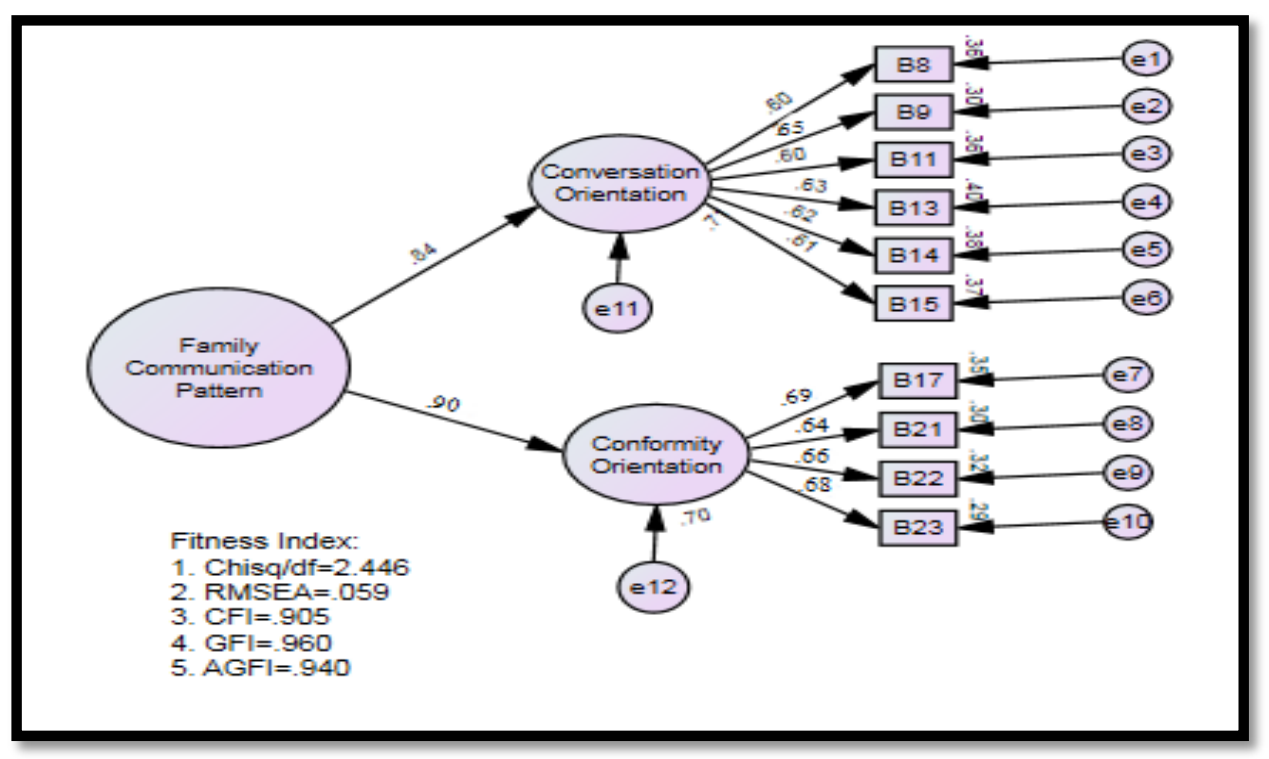

Figure 1: Measurement Model

The CFA had helped the researchers of this study to determine which items carried high impact on the measurement model. The results revealed that 6 items of the conversation orientation sub-construct and 4 items of the conformity orientation sub-construct had been retained in the model. The 6 items out of the 15 items of the conversation orientation that were acceptable and retained in the model included B8, B9, B11, B13, B14, and B15. In contrast, only 4 items out of the 11 items of the conformity orientation that were acceptable and retained in the model included B17, B21, B22, and B23 out of 11 items (Refer to Table 2). The factor loadings for each sub-construct ranged between 0.60 and 0.69 . Besides that, the loadings obtained from Family Communication Patterns for conversation orientation and conformity orientation stood at 0.84 and 0.90 which were higher than 0.60 of standardized loadings. Other than that, the fitness index was acceptable since chi-square normalized by the degree of freedom which was lower than 3.0; while the Root Mean Square Approximation (RMSEA) was below than 0.08; and the Comparative Fit Index (CFI), Goodness of Fit (GFI), as well as Adjusted Goodness of Fit (AGFI) were higher than 0.90. All the minimum index requirements were in line with those reported in many previous researches such as those carried out by Zainudin, Afthanorhan, Asri (2015), Bollen (1989), 
Afthanorhan\& Ahmad (2013), Antonakis et al., (2010), Afthanorhan\& Ahmad (2014) and Hair et al., (2009).

Table 2: The itemsobtained from theanalysis of theCFA

\begin{tabular}{|c|c|c|c|}
\hline \multicolumn{4}{|c|}{ Conversation Orientation } \\
\hline & Item & $\begin{array}{l}\text { Cronbach } \\
\text { Alpha }\end{array}$ & $\begin{array}{l}\text { Factor } \\
\text { Loading }\end{array}$ \\
\hline 1 & My family members often talk about our feelings and emotions. & 0.77 & 0.60 \\
\hline 2 & $\begin{array}{l}\text { My parents and I often have long, relaxed conversations about } \\
\text { nothing in particular. }\end{array}$ & 0.78 & 0.65 \\
\hline 3 & My parents encourage me to express my feelings. & 0.77 & 0.60 \\
\hline 4 & $\begin{array}{l}\text { We often talk as a family about things we have done during the } \\
\text { day. }\end{array}$ & 0.77 & 0.63 \\
\hline 5 & $\begin{array}{l}\text { My family members often talk about our plans and hopes for the } \\
\text { future. }\end{array}$ & 0.78 & 0.62 \\
\hline 6 & $\begin{array}{l}\text { My parents like to hear my childish opinion, even when I don't } \\
\text { agree with them. }\end{array}$ & 0.77 & 0.61 \\
\hline & \multicolumn{3}{|l|}{ Conformity Orientation } \\
\hline 1 & In our home, my parents usually have the last word. & 0.77 & 0.69 \\
\hline 2 & When I am at home, I am expected to obey my parents' rules. & 0.77 & 0.64 \\
\hline 3 & $\begin{array}{l}\text { My parents often say things like "You'll know better when you } \\
\text { grow up" }\end{array}$ & 0.80 & 0.66 \\
\hline 4 & $\begin{array}{l}\text { My parents often say things like "My ideas are right and you } \\
\text { should not question them". }\end{array}$ & 0.76 & 0.68 \\
\hline
\end{tabular}

Table 2 shows that the items retained in the model together with their Cronbach Alpha and Factor Loading values. For conversation orientation, all items had high reliability indicating that these items were reliable for this study. Meanwhile, the CFA disclosed that item B9 that is "My parents and I often have long, relaxed conversations about nothing in particular" carried the most loading in the model. Like conversation orientation, conformity orientation too have high reliability. In the conformity orientation model, item B17 was found to carry the most loading in comparison to the other loading of the item for example, "In our home, my parents usually have the last word". Subsequently, percentages of respondents who agreed with B9 and B17 were identified as shown by the bar chart below. The results for Item B9 and B17 from Figure 2 indicate that more than $50 \%$ of respondents had agreed with this particular item. 


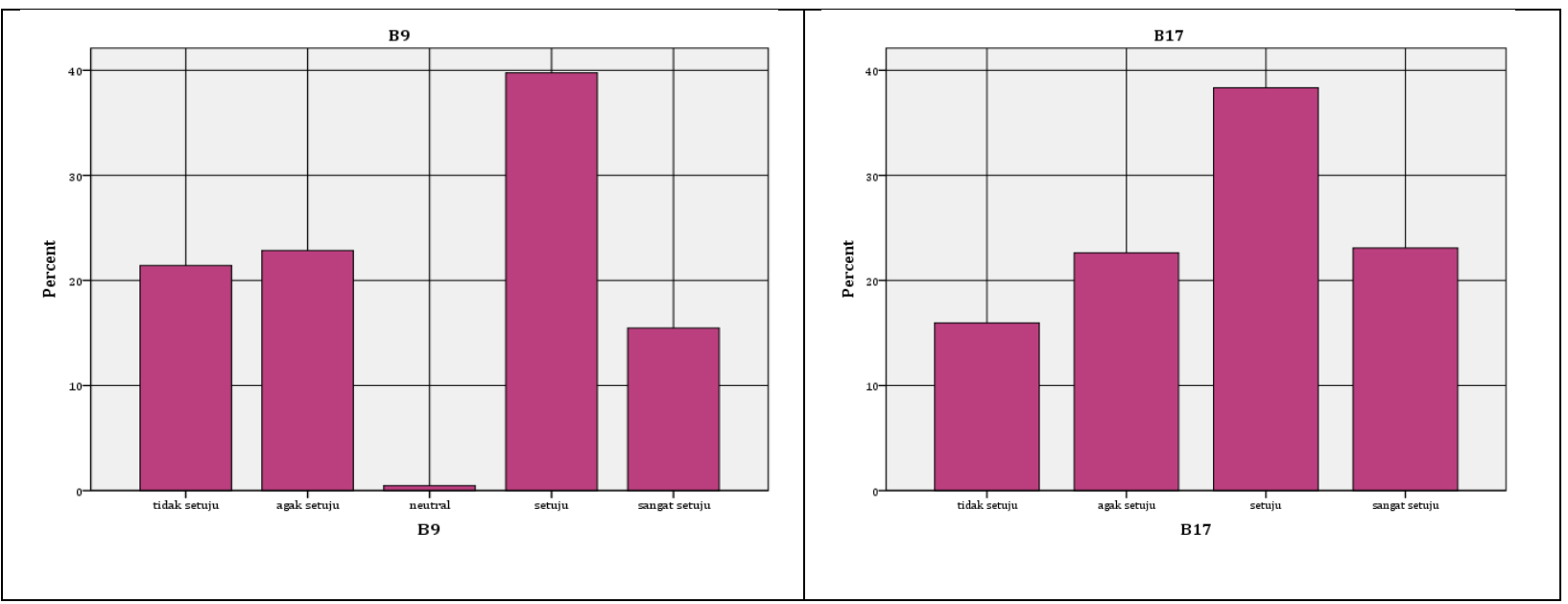

Figure 2: Bar Chart

\section{Conclusion}

Based on findings discussed above, it can be then be concluded that the model of Family Communication Patterns as the second order construct can be appropriately used to measure conversation orientation and conformity orientation via structural equation modeling. Other than that, it should also be noted that this application would enable items to be identified as those that have quality hence, used in a good model. Last but not least, it is also worth noting that the model can now be employed to examine the importance of items in each sub-construct involving conversation orientation and conformity orientation. As such, an in-depth study of the 6 items of conversation orientation and the 4 items of conformity orientation that have been highlighted in this study can be undertaken in the future.

\section{References}

Afthanorhan, W. M. A. B. W., \& Ahmad, S. (2014). Path Analysis in Covariance-Based Structural Equation Modeling with Amos 18.0. European Journal of Business and Social Sciences 2 (6), 10.

Afthanorhan, W. M. A. B. W., Ahmad, S. (2013). Modeling a High Reliability and Validity by using Confirmatory Factor Analysis on five latent constructs: Volunteerism Program.International Research Journal Advanced Engineer and Scientific Technology (IRJAEST).

Antonakis, J., Bendahan, S., Jacquart, P., \&Lalive, R. (2010). On making causal claims: A review and recommendations. The Leadership Quarterly,21(6), 1086-1120.

Awang, Z., Afthanorhan, A., \&Mamat, M. (2016). The Likert Scale analysis using parametric based structural equation modeling (SEM). Computational Methods in Social Sciences, 4(1), 13.

Bakar, A.A., \&Afthanorhan, A. (2016).Confirmatory Factor Analysis on Family Communication Patterns Measurement. Procedia-Social and Behavioral Sciences, 219, 33-40.

Bollen, K. A. (1989). A new incremental fit index for general structural equation models. Sociological Methods \& Research, 17(3), 303-316. 
Braithwaite, D. O., McBride, M. C., \&Schrodt, P. (2003). "Parent teams" and the everyday interactions of co-parenting in stepfamilies.Communication Reports. 16(2): 93-111.

Caro, D.H. (2011). Parent-child communication and academic performance: Associations at the within- and between-country level. Journal Educational Researh, volume 3 (2), 15-37.

Chaffee, S. H., McLeod, J. M., \& Atkin, C. K. (1971).Parental influence on adolescent media use.American Behavioral Scientist. 14: 323-340.

Chaffee, S. H., McLeod, J. M., \&Wackman, D. B. (1972).Family communications patterns and adolescent political participation. In J. Dennis (Ed.), Socialization to Politics: A Reader. N.Y.: Wiley.

Chan, K., \& McNeal, J. U. (2003).Parent-child communications about concumption and advertising in China.Journal of Consumer Marketing. 20 (4): 317-334.

Fosco,G.M.,\&Grych, J.H. (2010).Adolescent triangulation into parental conflicts: longitudinal implications for appraisals and adolescent-parent relations. Journal of Marriage and Family, 72(2), 254-266.

Galvin, M.K, Braithwaite, O.D, \&Baylund, L.C. (2015). Family Communication: Cohesion and change. (9 ed). Pearson Education, Inc.

Hair, J. F., Black, W. C., Babin, B. J., Anderson, R. E., \& Tatham, R. L. (2009). Análisemultivariada de dados.Bookman. 595-611.

Koerner, A., \& Fitzpatrick, M.A. (2004).Communication in intact families.In A. Vangelisti (Ed,), Handbook of family communication (pp. 177-196). Mahwah, NJ: Lawrence Erlbaum Associates, Inc.

Laursen, B. \& Collins, W. (2004).Parent-child communication during adolescence.https://www.researchgate.net/publication/256444591Parent-child.

McLeod, J. M., \& Chaffee, S. H. (1972).The construction of social reality. In L. D. Ritchie, "Family communication patterns: An epistemic analysis and conceptual reinterpretation". Communication Research. 18 (4): 548-565.

Park, H. (2008). The varied educational effects of parent-child communication: A com- parative study of fourteen countries. Comparative Education Review, 52 (2), 219- 243.

Simpkins, S. D., Weiss, H. B., McCartney, K., Kreider, H. M., \& Dearing, E. (2006).Motherchild relationship as a moderator of the relation between family educatio- nal involvement and child achievement. Parenting: Science and Practice, 6, 49- 57.

ZainudinAwang., Afthanorhan, A., \&Asri, M. A. M. (2015). Parametric and Non Parametric Approach in Structural Equation Modeling (SEM): The Application of Bootstrapping. Modern Applied Science, 9(9), 58. 